\title{
PENGARUH MODEL PEMBELAJARAN QUANTUM LEARNING TERHADAP KEMAMPUAN PEMECAHAN MASALAH MATEMATIKA SISWA KELAS VIII SMP PGRI 02 NGAJUM
}

\author{
Titik Riati ${ }^{1}$, Nur Farida ${ }^{2}$ \\ ${ }^{1}$ Program Studi Pendidikan Matematika, Universitas Kanjuruhan Malang \\ t2_riyanti@ymail.com \\ ${ }^{2}$ Program Studi Pendidikan Matematika, Universitas Kanjuruhan Malang \\ nurfarida@unikama.ac.id
}

\begin{abstract}
Abstrak : Tujuan utama dari pengajaran matematika adalah untuk membekali siswa dengan kemampuan berfikir kritis, logis, sistematis dan memiliki sikap objektif serta disiplin dalam memecahkan suatu permasalahan matematika. Pemecahan masalah merupakan kompetensi strategi yang ditunjukkan siswa dalam memahami, pendekatan dan strategi pemecahan masalah, serta penyelesaian model untuk menyelesaikan masalah. Model pembelajaran quantum learning merupakan salah satu model pembelajaran yang dapat meningkatkan kemampuan pemecahan masalah matematika, yang mengedepankan unsur-unsur kebebasan, santai, menyenangkan, dan menggairahkan. Tujuan dari penelitian ini adalah untuk mengetahui pengaruh model pembelajaran quantum learning terhadap kemampuan pemecahan masalah matematika siswa SMP PGRI 02 Ngajum.

Metode penelitian yang digunakan dalam penelitian ini adalah metode penelitian eksperimen. Penelitian ini dilakukan SMP PGRI 02 Ngajum. Populasi dalam penelitian ini adalah siswa kelas VIII dan sampel penelitian ini yaitu kelas VIII A sebagai kelompok eksperimen dan kelas VIII B sebagai kelompok kontrol yang masing-masing berjumlah 19 siswa. Kelompok eksperimen diberi perlakuan dengan menggunakan model quantum learning sedangkan kelompok kontrol menggunakan pendekatan konvensional. Pengukuran kemampuan pemecahan masalah matematika dilakukan dengan menggunakan tes kemampuan pemecahan masalah berbentuk uraian yang harus diselesaikan dengan langkah-langkah pemecahan masalah menurut Polya.

Berdasarkan pengolahan data dan analisis data dengan menggunakan uji hipotesis diperoleh $t_{\text {hitung }}=3,446>t_{\text {tabel }}=2,028$, maka $\mathrm{H}_{0}$ ditolak dan $\mathrm{H}_{1}$ diterima sehingga dapat disimpulkan bahwa ada pengaruh model pembelajaran quantum learning terhadap kemampuan pemecahan masalah matematika siswa SMP PGRI 02 Ngajum pada pokok bahasan SPLDV.

Kata Kunci: Model quantum learning, kemampuan pemecahan masalah matematika
\end{abstract}

\section{Pendahuluan}

Pada era globalisasi seperti sekarang ini, pendidikan matematika berkembang seirama dengan perkembangan ilmu pengetahuan dan teknologi. Hal ini karena matematika merupakan ilmu universal yang mendasari perkembangan teknologi modern yang dibutuhkan hampir di setiap sendi kehidupan manusia. Oleh karena itu, matematika perlu dikuasai sejak dini agar mampu menguasai dan menciptakan teknologi di masa depan.

Berdasarkan peraturan menteri pendidikan nasional nomor 22 tahun 2006 tentang standar isi untuk satuan pendidikan dasar dan menengah dinyatakan bahwa pembelajaran matematika difokuskan pada pendekatan pemecahan masalah yang mencakup masalah tertutup dengan solusi tunggal, masalah terbuka dengan solusi tunggal, dan masalah dengan berbagai cara 
penyelesaian dengan pembelajaran dimulai dengan pengenalan masalah sesuai dengan situasi.

Dalam BSNP 2006, mata pelajaran matematika bertujuan agar siswa memiliki kemampuan memecahkan masalah yang meliputi kemampuan memahami masalah, merancang model matematika, menyelesaikan soal, dan menafsirkan solusi yang diperoleh. Berdasarkan tujuan tersebut tampak bahwa arah atau orientasi pembelajaran matematika adalah kemampuan pemecahan masalah, kemampuan penalaran, dan kemampuan komunikasi matematika.

Pada kenyataannya bahwa matematika itu merupakan pelajaran yang kurang disenangi oleh siswa. Banyak siswa yang cenderung menghindar dari pelajaran matematika. Trends in International Mathematics and Scence Study (TIMSS, 2015), melaporkan hasil penelitiannya bahwa kemampuan matematika siswa Indonesia kelas IV berada pada peringkat 45 dari 50 negara peserta dengan perolehan rataan 397. Selain itu, kemampuan matematika siswa Indonesia berada pada peringkat 63 dari 69 negara sebagaimana yang dilansir oleh Programme for International Student Assessment (PISA, 2015).

Menurut Endahwari (2010), untuk mengatasi rendahnya kemampuan pemecahan masalah siswa maka guru harus selalu memberikan soal-soal matematika yang merupakan penerapan dari materi yang sedang dipelajari dalam kehidupan sehari-hari. Salah satu materi paling penting dalam matematika yang menyangkut berbagai persoalan yang berupa pemecahan masalah yakni materi tentang Sistem Persamaan Linear Dua Variabel (SPLDV).

Banyak upaya yang dapat dilakukan untuk menciptakan suasana belajar yang kondusif agar siswa mengalami pembelajaran bermakna, diantaranya yaitu mencoba berbagai model pembelajaran yang dianggap sesuai dengan kondisi siswa dikelas dan materi yang akan diajarkan. Salah satunya yaitu menggunakan model pembelajaran quantum learning.

Model pembelajaran adalah serangkaian langkah pembelajaran yang tersusun secara sistematis dari awal hingga akhir yang didalamnya terdapat strategi, pendekatan, metode, dan teknik pembelajaran. Quantum learning adalah kiat, petunjuk, strategi dan seluruh proses belajar yang dapat mempertajam pemahaman dan daya ingat, serta membuat belajar sebagai suatu proses yang menyenangkan dan bermanfaat (DePorter \& Hernacki, 2011:16). Pembelajaran quantum learning mulai dikenal di Super Camp, sebuah program yang mengkombinasikan penumbuhan rasa percaya diri, keterampilan belajar, dan keterampilan berkomunikasi dalam suatu lingkungan yang menyenangkan. Perusahaan yang melahirkan Super Camp adalah Learning Forum.

DePorter dan Hernacki (2011:14) menyatakan bahwa quantum learning berakar dari upaya Dr. Georgi Lezanov, seorang pendidik berkebangsaan Bulgaria yang bereksperimen dengan apa yang disebutnya sebagai "suggestology" atau "suggestopedia". Istilah lain dari suggestology adalah accelerated learning atau "pemercepat belajar" yakni metode yang memungkinkan siswa untuk belajar dengan kecepatan yang mengesankan dengan upaya yang normal dan diikuti dengan kegembiraan. Selain suggestology dan accelerated learning dalam quantum learning juga menggabungkan program neurolinguistik (NPL) " Neuro Liguistic Program”, yaitu suatu penelitian tentang bagaimana otak mengatur informasi. Program ini meneliti hubungan antara bahasa dan perilaku dan dapat digunakan 
untuk menciptakan jalinan pengertian antara siswa dan guru.

Wena (2008:160) menyatakan model pembelajaran quantum learning merupakan cara baru yang memudahkan proses belajar, yang memadukan unsur seni dan pencapaian yang terarah, untuk berbagai mata pelajaran. Pembelajaran quantum learning memiliki falsafah bahwa proses belajar mengajar akan berhasil dengan efektif, apabila aktivitas pembelajaran dilakukan dengan menyenangkan. Dalam hal ini, belajar dikatakan menyenangkan jika suasana belajar komunikatif, rileks, dan tidak tegang (Yosodipuro, 2013).

Abdurrahman

menjelaskan adapun langkah-langkah dari model pembelajaran quantum learning adalah sebagai berikut:

a. Penataan lingkungan belajar

Seperti telah diungkapkan, bahwa quantum learning mementingkan adanya lingkungan belajar yang kondusif bagi pembelajar, maka dalam proses belajar dan mengajar diperlukan penataan lingkungan yang dapat membuat siswa merasa betah dalam belajarnya, dengan penataan lingkungan belajar yang tepat juga dapat mencegah kebosanan dalam diri siswa.

b. Kekuatan AMBAK (Apa Manfaatnya Bagi $\mathrm{Ku}$ )

Tumbuhkan minat dengan memuaskan "Apakah manfaat bagiku" (AMBAK) dan manfaat kehidupan pelajar". Ambak adalah motivasi yang didapat dari pemilihan secara mental antara manfaat dan akibat-akibat suatu keputusan. Kegiatan pada tahap ini merupakan kegiatan apersepsi dalam pembelajaran.

c. Membiasakan Membaca

Salah satu aktivitas yang cukup penting adalah membaca. Karena dengan membaca akan menambah perbendaharaan kata, pemahaman, menambah wawasan dan daya ingat akan bertambah.

\section{d. Membiasakan mencatat}

Belajar akan benar-benar dipahami sebagai aktivitas kreasi ketika sang siswa tidak hanya bisa menerima, melainkan bisa mengungkapkan kembali apa yang didapatkan menggunakan bahasa hidup dengan cara dan ungkapan sesuai gaya belajar siswa itu sendiri. Hal tersebut dapat dilakukan dengan memberikan simbol-simbol atau gambar yang mudah dimengerti oleh siswa itu sendiri, simbol-simbol tersebut dapat berupa tulisan.

e. Bebaskan gaya belajarnya

Ada beberapa macam gaya belajar yang dipunyai oleh siswa, gaya belajar tersebut yaitu: visual, auditorial dan kinestetik. Dalam quantum learning guru hendaknya memberikan kebebasan dalam belajar pada siswa dan janganlah terpaku pada satu gaya belajar saja. Pemberian intruksi yang tepat dan sesuai dengan gaya belajar siswa, tentunya akan berpengaruh pada keberhasilan pencapaian tujuan siswa tersebut.

f. Jadikan anak lebih kreatif

Siswa yang kreatif adalah siswa yang ingin tahu, suka mencoba dan senang bermain. Dengan adanya sikap kreatif yang baik siswa akan mampu menghasilkan ide-ide yang segar dalam belajarnya.

g. Memupuk sikap juara

Banyak dari kita sebagai pendidik telah memberi pujian positif bagi siswa, pujian positif yang diberikan bagi siswa tentunya akan menumbuhkan sugesti positif pula. Hal ini yang akan mendorong sikap juara bagi siswa.

h. Melatih kekuatan motorik anak

Kekuatan motorik sangat diperlukan dalam belajar anak, sehingga anak perlu dilatih untuk mendapatkan kekuatan motorik yang baik. 
Model pembelajaran quantum learning memiliki beberapa kekurangan diantaranya adalah membutuhkan pengalaman yang nyata, waktu yang cukup lama untuk menumbuhkan motivasi dalam belajar, dan kesulitan mengidentifikasi tipe kecerdasan siswa. Keunggulan model pembelajaran quantum learning antara lain pembelajaran quantum learning menekankan pengembangan akademis dan keterampilan, guru mampu menyatu dan membaur pada dunia siswa sehingga guru biasa lebih memahami siswa, pembelajaran quantum learning sebagai salah satu model pembelajaran yang dapat memadukan antara berbagai sugesti positif dan interaksinya dengan lingkungan. Lingkungan belajar yang menyenangkan dapat menimbulkan motivasi pada diri siswa sehingga secara langsung dapat mempengaruhi kemampuan siswa dalam memecahkan masalah.

Kusumawati (Chotimah, 2014) menyatakan kemampuan pemecahan masalah matematika adalah kemampuan mengidentifikasi unsur-unsur yang diketahui, ditanyakan dan kecukupan unsur yang diperlukan, mampu membuat atau menyusun model matematika, dapat memilih dan mengembangkan strategi pemecahan, mampu menjelaskan dan memeriksa kebenaran jawaban yang diperoleh. Adapun indikator kemampuan pemecahan masalah berdasarkan tahap pemecahan oleh Polya sebagai berikut:

Tabel 1. Indikator Kemampuan Pemecahan Masalah Berdasarkan Tahapan Pemecahan

\begin{tabular}{|c|c|}
\hline \multicolumn{2}{|c|}{ Masalah oleh Polya } \\
\hline $\begin{array}{c}\text { Tahap } \\
\text { Pemecahan } \\
\text { Masalah Oleh } \\
\text { Polya } \\
\end{array}$ & Indikator \\
\hline $\begin{array}{c}\text { Memahami } \\
\text { Masalah }\end{array}$ & $\begin{array}{l}\text { Siswa dapat menyebutkan } \\
\text { informasi-informasi yang } \\
\text { diberikan dan pertanyaan } \\
\text { yang diajukan }\end{array}$ \\
\hline
\end{tabular}

\begin{tabular}{cl}
\hline & Siswa memiliki rencana \\
Merencanakan & $\begin{array}{l}\text { pemecahan masalah yang } \\
\text { digunakan serta alasan } \\
\text { penggunaannya }\end{array}$ \\
\hline & $\begin{array}{l}\text { Siswa dapat memecahkan } \\
\text { masalah sesuai langkah- }\end{array}$ \\
Melakukan & langkah pemecahan masalah \\
Rencana & yang ia gunakan dengan \\
Pemecahan & hasil yang benar \\
\hline Memeriksa & $\begin{array}{l}\text { Siswa memeriksa kembali } \\
\text { Kembali }\end{array}$ \\
langkah pemecahan masalah \\
Pemecahan & yang ia gunakan \\
\hline
\end{tabular}

Menurut Amalia (2013), menyatakan bahwa penerapan model quantum learning memberikan dampak positif terhadap peningkatan kemampuan matematis siswa. Selain itu Rusmawati (2014) menunjukkan bahwa model pembelajaran quantum learning memberikan dampak positif terhadap motivasi dan hasil belajar matematika.

Berdasarkan uraian di atas, perlu dilakukan penelitian model pembelajaran kuantum yang berjudul "Pengaruh Model Pembelajaran Quantum Learning Terhadap Kemampuan Pemecahan Masalah Matematika Siswa Kelas VIII SMP PGRI 02 Ngajum Pada Pokok Bahasan Sistem Persamaan Linear Dua Variabel". Rumusan masalah dalam penelitian ini adalah adakah pengaruh peningkatan kemampuan pemecahan masalah matematika pada siswa yang menggunakan model pembelajaran quantum learning pada materi Sistem Persamaan Linear Dua Variabel di SMP PGRI 02 Ngajum.

Tujuan penelitian ini adalah untuk mengetahui pengaruh peningkatan kemampuan pemecahan masalah matematika pada siswa yang menggunakan model pembelajaran quantum learning dengan siswa yang pembelajarannya konvensional. Adapun manfaat penelitian ini antara lain: 1) dapat dijadikan salah satu masukan untuk memilih dan mengembangkan alternatif model pembelajaran quantum learning. 
2) penelitian ini untuk menambah wawasan dan keterampilan dalam menggunakan model quantum learning untuk meningkatkan kemampuan pemecahan masalah matematika. 3) penelitian ini dapat memberi pengalaman baru dan suasana belajar yang lebih nyaman dan menyenangkan disaat belajar matematika.

\section{Metode Penelitian}

Penelitian ini menggunakan pendekatan kuantitatif, metode yang digunakan dalam penelitian ini adalah metode penelitian eksperimen. Penelitian ini akan dilaksanakan di SMP PGRI 02 Ngajum Desa Babadan Kecamatan Ngajum Kabupaten Malang. Populasi dalam penelitian ini adalah seluruh siswa kelas VIII SMP PGRI 02 Ngajum, sedangkan sampel dalam penelitian ini yaitu kelas VIII A sebagai kelas eksperimen sebanyak 19 siswadengan model pembelajaran quantum learning dan kelas VIII B sebagai kelas kontrol sebanyak 19 siswa dengan model pembelajaran konvensional.

Variabel bebas dalam penelitian ini adalah model pembelajaran quantum learning, sedangkan variabel terikat dalam penelitian ini adalah kemampuan pemecahan masalah matematika siswa SMP kelas VIII. Data penelitian dikumpulkan melalui metode tes dan wawancara. Metode tes dilakukan untuk memperoleh data kemampuan pemecahan masalah matematika. Tes yang digunakan adalah tes dengan bentuk uraian yang sudah memenuhi syarat validitas dan reliabilitas. Metode wawancara digunakan untuk mengetahui tanggapan siswa dalam pembelajaran yang menggunakan model pembelajaran quantum learning.

Beberapa pengujian dalam analisis data penelitian ini antara lain: uji normalitas, uji homogenitas, uji linieritas, uji hipotesis, dan uji gain ternormalisasi.

\section{Hasil dan Pembahasan}

Penelitian tentang pembelajaran matematika dengan model pembelajaran quantum learning pada kelas eksperimen ini dailaksanakan sebanyak 4 kali pertemuan (8 jam pelajaran) yang terdiri atas 3 pertemuan untuk pelaksanaan pembelajaran dan satu pertemuan untuk tes kemampuan pemecahan masalah matematika. Materi dalam penelitian ini adalah Sistem Persamaan Linear Dua Variabel.

Pada pertemuan pertama peneliti memberi pretest pada kelas eksperimen maupun kelas kontrol untuk mengetahui kemampuan awal yang dimiliki siswa sebelum kedua kelas diberi treatment. Hal ini sesuai dengan pendapat Sutrisno (2012) yang menyatakan bahwa pelaksanaan tes sebelum perlakuan dilakukan untuk mengetahui pemahaman awal siswa.

Kegiatan pembelajaran pada setiap pertemuan diawali dengan kegiatan pendahuluan yaitu peneliti mengucapkan salam, berdo'a, memeriksa kehadiran siswa dan mengkondisikan situasi kelas untuk mengikuti kegiatan pembelajaran, dilanjutkan peneliti menyampaikan apersepsi, memberi motivasi kepada siswa, dan menyampaikan tujuan pembelajaran. Kemudian dengan bantuan guru peneliti mengarahkan siswa untuk membentuk kelompok dan meminta ketua kelompok untuk mengambil Lembar Kerja Kelompok (LKK) pada tiap kelompok.

Pada kegiatan inti, tahap pertama yang dilakukan peneliti adalah peneliti meminta siswa untuk membaca materi yang sudah ditampilkan di depan kelas kemudian peneliti memberi memberikan penjelasan sekilas dan meminta siswa untuk mencatat hasil diskusi masing- 
masing. Selanjutnya peneliti memberi tantangan kepada siswa untuk mempresentasikan ke depan kelas hasil penyelesaian masalah yang diperoleh dari hasil diskusi.

Pada kegiatan penutup, peneliti bersama-sama siswa membuat kesimpulan dari materi yang telah dipelajari. Setelah itu, guru mengakhiri pelajaran dengan mengucapkan salam.

Pada pertemuan terakhir peneliti memberi posttest pada kedua kelas untuk mengetahui kemampuan pemecahan masalah matematika. Adapun aspek kemampuan pemecahan masalah matematika siswa pada penelitian ini yaitu: 1) memahami masalah; 2) merencanakan penyelesaian; 3) menyelesaikan masalah sesuai rencana; dan 4) melakukan pengecekan kembali. Rekapitulasi hasil perhitungan nilai pretest dan posttest dapat dilihat pada Tabel 2 berikut ini:

Tabel 2 Rekapitulasi Data Hasil Pretest dan Posttest

\begin{tabular}{lllll}
\hline \multirow{2}{*}{ Statistik } & \multicolumn{2}{l}{$\begin{array}{l}\text { Kelompok } \\
\text { Eksperimen }\end{array}$} & $\begin{array}{l}\text { Kelompok } \\
\text { Kontrol }\end{array}$ \\
\cline { 2 - 5 } & Pretest & $\begin{array}{l}\text { Post- } \\
\text { tes }\end{array}$ & Pretest & $\begin{array}{l}\text { Post- } \\
\text { tes }\end{array}$ \\
\hline $\begin{array}{l}\text { Jumlah } \\
\text { Siswa }\end{array}$ & 19 & 19 & 19 & 19 \\
\hline Rata-rata & 53,86 & 81,05 & 54,56 & 68,29 \\
\hline Modus & 53,33 & 85,00 & 50,00 & 67,50 \\
\hline Varian & 87,98 & 93,97 & 48,41 & 66,01 \\
\hline $\begin{array}{l}\text { Simpangan } \\
\text { Baku }\end{array}$ & 9,13 & 9,44 & 6,77 & 7,91 \\
\hline Jangkauan & 33,33 & 35,00 & 26,67 & 32,50 \\
\hline $\begin{array}{l}\text { Nilai } \\
\text { Tertinggi }\end{array}$ & 73,33 & 92,50 & 66,67 & 82,50 \\
\hline $\begin{array}{l}\text { Nilai } \\
\text { Terendah }\end{array}$ & 40,00 & 57,50 & 40,00 & 50,00 \\
\hline
\end{tabular}

Berdasarkan Tabel 1 dapat dilihat bahwa nilai rata-rata pada kelas eksperimen sebesar 81,05. Sedangkan pada elas kontrol nilai rata-rata yang diperoleh sebear 68,29. Berdasarkan ratarata yang diperoleh dapat disimpulkan bahwa kemampuan akhir siswa pada kelas eksperimen lebih besar dari pada kelas kontrol.

Sebelum melakukan uji hipotesis maka harus dilakukan uji prasyarat yang meliputi uji normalitas yang bertujuan untuk mengetahui bahwa kedua sampel berdistribusi normal. Setelah mendapatkan hasil dari uji normalitas maka dilanjutkan dengan uji homogenitas data. Pada uji normalitas dan uji homogenitas diperoleh bahwa kedua data berdistribusi normal dan homogen.

Berdasarkan hasil perhitungan uji t dengan taraf signifikansi 5\% diperoleh $t_{\text {hitung }}$ sebesar 3,446 dan $t_{\text {tabel }}$ sebesar 2,028. Dengan membandingkan hasil $t_{\text {hitung }}$ dan $t_{\text {tabel }}$ dapat disimpulkan $t_{\text {hitung }}>$ $t_{\text {tabel }}$ maka $\mathrm{H}_{0}$ ditolak atau $\mathrm{H}_{1}$ diterima. Sehingga dapat disimpulkan bahwa ada pengaruh model pembelajaran quantum learning terhadap kemampuan pemecahan masalah matematika pada siswa kelas VIII SMP PGRI 02 Ngajum.

\section{Kesimpulan}

Berdasarkan hasil penelitian dan pembahasan, dapat disimpulkan bahwa model pembelajaran quantum learning ini ternyata mampu meningkatkan kemampuan pemecahan masalah matematika siswa kelas VIII. Hal ini dibuktikan dengan skor rata-rata hasil tes kemampuan pemecahan masalah matematika kelas eksperimen sebesar 81,05 dan kelas kontrol 68,29.

Berdasarkan hasil uji hipotesis dengan dibantu program IBM SPSS Statistic 22 diperoleh $t_{\text {hitung }}$ sebesar 3,446 dan $t_{\text {tabel }}$ sebesar 2,028, karena $t_{\text {hitung }}>$ $t_{\text {tabel }}$ maka $\mathrm{H}_{0}$ ditolak atau $\mathrm{H}_{1}$ diterima diterima. Sehingga dapat disimpulkan bahwa ada pengaruh model pembelajaran quantum learning terhadap kemampuan pemecahan masalah matematika pada siswa kelas VIII SMP PGRI 02 Ngajum. Dari kesimpulan penelitian yang dilakukan, ada beberapa saran yang 
ditunjukkan kepada pihak-pihak yang berkepentingan antara lain: Diharapkan guru lebih inovatif dalam hal menggunakan model pembelajaran, supaya pembelajaran matematika menjadi suatu pembelajaran yang menyenangkan dan bermakna, diharapkan siswa lebih rajin belajar dan berlatih memecahkan masalah matematika, bagi pembaca penelitian ini dapat memberikan khasanah dan wawasan pengetahuan tentang proses pembelajaran di dalam dunia pendidikan.

\section{Daftar Rujukan}

Abdurrrahman, Alwiyah. 2009. Quantum Learning: Membiasakan Belajar Nyaman dan Menyenangkan, terjemahan Quantum Learning by DePorter, Bobbi \& Mike Hernacki, Bandung: Kaifa.

Amalia, Lia. 2013. Pengaruh Penerapan Quantum Learning Prinsip Tandur Terhadap Peningkatan Kemampuan Komunikasi Matematis pada Siswa, Skripsi. Bandung: Univesitas Pendidikan Indonesia.

Badan Standar Nasional Pendidikan, 2006. Standar isi untuk satuan pendidikan dasar dan menengah. Jakarta: BSNP.

Chotimah, N.H. 2014. Pengaruh Model Pembelajaran Generatif (MPG) Terhadap Kemampuan Pemecahan Masalah dan Desposisi Matematis Siswa di Kelas X pada SMA Negeri 8 Palembang, Skripsi. Palembang: Universitas PGRI Palembang.

DePorter, B. et al. 2011. Quantum Teaching. Bandung: Kaifa.
Endahwari, Sapta, Dyah. 2010, Eksperimentasi Pendekatan Pemecahan Masalah Polya dalam metode Diskusi Kelomok Pada Soal Cerita Sistem Persamaan Linear Dua Variabel Ditinjau dari Kreativitas Belajar Siswa Kelas VIII Semester Gasal SMP Negeri 10 Surakarta Tahun Pelajaran 2009/2010, Skripsi. Surakarta: Universitas Sebelas Maret.

Iswandi, Hazrul. 2015. Sekelumit Dari Hasil PISA 2015 yang Baru Dirilis. (http://www.ubaya.ac.id/2014/conte nt/articles_detail/230/Sekelumit-

Dari-Hasil-PISA-2015-Yang-Baru-

Dirilis.html). Diakses 6 Desember 2016.

Rusmawati, Dewi. 2014. Pengaruh Model Quantum Learning Terhadap Motivasi Belajar dan Hasil Belajar Siswa Kelas VIII SMP Negeri 2 Salatiga Tahun Pelajaran 2013/2014. Skripsi: Fakultas Keguruan dan Ilmu Pendidikan. Universitas Kristen Satya Wacana.

Sutrisno, Leo. 2011. Pengambilan Sampel.(http://www.scribd.com) Diakses September 2013).

Wena, Made. 2008. Strategi Pembelajaran Inovatif Kontenpoler Suatu Tinjauan Konseptual Operasional. Jakarta: Alfabeta.

Yosodipuro, A. 2013. Siswa Senang Guru Gemilang. Strategi Mengajar yang Menyenangkan dan Mendidik dengan Cerdik. Jakarta: PT Gramedia Pustaka Utama. 